\title{
GST - Goods and Services Tax in India
}

\section{Keshap PK*}

Associate Professor, Education Consultant of India, Ludhiana, India

\section{Introduction}

India is almost ready to roll into the regime of GST from April 1, 2016. The introduction of GST will change the market dynamics and it will quite interesting to see how the business enterprises and companies will attune to the new tax regime.

Manufacturers will be able to have a sigh of relief from multiple taxation and bureaucratic interventions in marketing of their products. Manufacturing and marketing, producing and selling will in the opinion of business experts will be bit hassle free and save time and energy of the manufacturer and producers on effective deliverables.

The GST is a value added tax to be levied on all goods and services throughout India. The revenue generated from GST will be shared between the States and Centre in a definite ratio to be agreed upon by the States and Centre.

GST levied on Inter-State transactions will be shared by the States and Centre. Branch transfers too are subject to IGST (Inter State GST).

\section{Historical Background}

2006: In the budgetary speech, Finance Minister of India, announce introduction of the Goods and Service Tax w.e.f April 1, 2010.

2009: First task force was set up and its first discussion report was presented.

2010: Date of introduction of the GST was revised to April 1, 2013.

2011: The cabinet of India approved the Constitutional Amendment Bill and placed it before the Parliament. This amendment was further referred to the Standing Committee constituted for the specific purpose.

2012: The Standing committee placed negative list and provision of Service Rules.

2013: Three sub-committees were formed. Their chief work was to sort out the contentious issues. These sub-committees after deliberations submitted the report to the Standing Committee and the amended bill was sent to the States for consideration.

2014: Finance Minister Releases the funds to compensate the States and Constitution Amendment Bill is introduced in the Lok Sabha.

2015: From April 1, 2016, India will enter into the new regime of taxation i.e. Goods and Services Tax.

Experts of business and the business community feels that the new regime will broaden the tax base, foster a common market across the entire country and lower the cost of logistics.

Many hitches were tackled by the Government and lot of parleys with the stakeholders were held for removing the uncertainty felt by business people with reference to the implementation of GST and the direct and indirect impact on the companies and market at large.

\section{Inclusions in GST}

Introduction of the GST will eliminate multifarious taxes and duties being levied at present. They include:
- Central Excise

- Service Tax

- Additional Excise duties of customs in lieu of central excise and sales tax

- Cess on additional duties of customs

- State Value added tax (VAT)

- Central Sales Tax

- Entry Tax

- Octroi

- Local Entry Tax

\section{Exclusions in GST}

- Basic Customs Duty

- Cess on Basic Customs Duty

- Entertainment Tax levied by Panchayat, municipality, regional or district council.

- Alcohol for human consumption

- Tobacco and tobacco products

- Crude, Diesel, petrol, natural gas, air turbine fuel.

\section{Conclusion}

The GST regime will replace multiple indirect taxes with a single tax. Study of the National Council of Applied Economic Research opines the rolling out of GST will boost India's GDP by $0-9$ to $1.7 \%$. In addition, it provides an efficient way to mobiles revenue and reduces the fiscal deficit. GST will also help ease the burden of multiple tax compliance which in turn will boost the manufacturing and production and lower the cost component as well as tax implications. GST will make the taxation process and compliance procedure easier, effective and business friendly.

*Corresponding author: Keshap PK, Associate Professor, Education Consultan of India, Ludhiana, India, Tel: +911612455560; E-mail: mpi678@gmail.com

Received July 15, 2015; Accepted October 28, 2015; Published November 03 , 2015

Citation: Keshap PK (2015) GST - Goods and Services Tax in India . J Glob Econ 3: 159. doi:10.4172/2375-4389.1000159

Copyright: @ 2015 Keshap PK. This is an open-access article distributed under the terms of the Creative Commons Attribution License, which permits unrestricted use, distribution, and reproduction in any medium, provided the original author and source are credited. 